\title{
CULTIVATION OF THE EDIBLE MUSHROOM OUDEMANSIELLA CANARII (JUNGH.) HÖHN. IN LIGNOCELLULOSIC SUBSTRATES
}

\author{
Marcelo José Silveira Ruegger ${ }^{*}$; Sâmia Maria Tauk Tornisielo' Vera Lúcia Ramos Bononi²; Marina Capelari² \\ ${ }^{1}$ Centro de Estudos Ambientais, Universidade Estadual Paulista, Rio Claro, SP, Brasil; ${ }^{2}$ Seção de Micologia e Liquenologia, \\ Instituto de Botânica, São Paulo, SP, Brasil.
}

Submitted: January 15, 2001; Returned to authors for corrections: April 26, 2001; July 23, 2001

\begin{abstract}
The edible mushroom Oudemansiella canarii (Jungh.) Höhn is common in the Brazilian territory, being found in different biomas, where they colonize several plant species. In this study, the $O$. canarii cultivation was evaluated in polypropilene bags containing sugar-cane bagasse $(200 \mathrm{~g})$ or eucalyptus sawdust $(200 \mathrm{~g})$ supplemented with wheat bran $(50 \mathrm{~g})$. The composts were sterilized at $121^{\circ} \mathrm{C}$ for 1 hour, after cooling they were inoculated with $3 \mathrm{~g}$ of spawn and then remained incubated at $25^{\circ} \mathrm{C}$ until the basidiomata primordia formation. The mushrooms, harvested after the pilei opening, presented varied sizes reaching $9 \mathrm{~cm}$ of diameter and $10 \mathrm{~cm}$ of height. The fresh mushrooms presented mild taste and soft consistency. When kept at $4^{\circ} \mathrm{C}$, they maintained good appearance and good consistency for 7 days. In a period of 60 days, the largest basidiomata production was obtained in the compost with sugar-cane bagasse, showing greater productivity $(4.47 \% \pm 1.34)$, biological efficiency $(55.66 \% \pm 20.41)$ and compost consumption $(38.78 \% \pm 4.59)$ averages. Wilcoxon's non-parametric statistical analysis used to compare the biomass production in the two composts, showed significant differences at $5 \%$ significance level.
\end{abstract}

Key words: Oudemansiella canarii, basidiomycetes, mushroom, solid substrates, biodegradation

\section{INTRODUCTION}

The lignocellulose bioconversion is naturally slow and limited to a few microorganisms, due to its complex and heterogeneous structure. The white rottenness fungi stand out for being especially active as lignocellulose decomposers. They are the only fungi that can take the complete lignin mineralization (9). These microorganisms are able of delignifying the wood selectively, modifying or degrading the lignin and transforming the lignocellulosic substrates of this decomposition in high quality feed for ruminants (1), or utilizing the polysaccharides liberated by hydrolysis and fermentation, in order to produce fuels and other chemicals $(3,8)$. Mushrooms can efficiently decompose lignocellulosic substrates without the need of pretreatments. Thus a great variety of agricultural residues can be used as substrates for food production and simultaneously favor its recycling (3).
There are a few species of mushrooms cultivated for food (11). Of these, only six are grown on an industrial scale: Flammulina velutipes, Lentinula edodes, Volvariella volvacea, Pleurotus ostreatus, Agaricus brunnescens and Agaricus bitorquis (7). In Brazil, until 1995, only A. bisporus, P. ostreatus and L. edodes were cultivated commercially (4). Despite the little use of mushrooms in foods in Brazil, these fungi, in addition to their good taste, have a high nutritional value, being good sources of minerals and vitamins. In some countries, most notably China and Japan, where the mushrooms are traditionally consumed, certain species are used due to their medicinal and tonic properties (2).

Oudemansiella canarii, an edible mushroom of the Agaricales, is common in the Brazilian territory. It is found in different biomas colonizing many plant species, including Brazilian pine. In this study, the CCB 179 strain was evaluated for basidiomata production on sugar-cane bagasse and eucalyptus sawdust.

\footnotetext{
* Corresponding author. Mailing address: Centro de Estudos Ambientais, UNESP, Av. 24-A, 1515. 13506-900, Rio Claro, SP, Brasil. Telefax: (+5519) 534-0122. E-mail: mjsr@siteplanet.com.br
} 


\section{MATERIALS AND METHODS}

\section{Microorganism}

The pure culture of Oudemansiella canarii (CCB 179) came from the Culture Collection of Basidiomycetes (CCB) of the Instituto de Botânica, São Paulo, Brazil. The mycelium was transferred from the stock culture to the center of a Petri dish containing malt-extract agar (dextrose $2 \%$, malt-extract $2 \%$, peptone $0.1 \%$, agar $2 \%$ ) and incubated at $25^{\circ} \mathrm{C}$ for 15 days.

\section{Spawn preparation}

Three pieces of $1.5 \mathrm{~cm}^{2}$ of malt-extract agar medium colonized by the fungus mycelium were inoculated in a $500 \mathrm{~mL}$ glass jar, in which $3 / 4$ of the volume contained wheat grains, previously boiled for $15 \mathrm{~min}$, and added of $1 \% \mathrm{CaCO}_{3}(\mathrm{w} / \mathrm{w})$. The jar was incubated at $25^{\circ} \mathrm{C}$ for three weeks, until total substrate colonization.

\section{Culture conditions}

$O$. canarii was cultivated in sugar-cane bagasse $(200 \mathrm{~g})$ or eucalyptus sawdust $(200 \mathrm{~g})$ supplemented with wheat bran $(50 \mathrm{~g})$ in fourteen repetitions. The substrates were mixed manually in trays and tap water was added to reach $70 \%$ moisture. The substrates were packed in polypropilene bags and autoclaved at $121^{\circ} \mathrm{C}$ for 60 minutes. The humidity was calculated in relation to the components dry weight. The volume in the bags was c.a. 3.4 liters, showing $17 \mathrm{~cm}$ diameter and $15 \mathrm{~cm}$ height. After sterilization, the bags containing the composts were aseptically inoculated with $3 \mathrm{~g}$ of spawn and incubated at $25^{\circ} \mathrm{C}$ for three weeks. The bags were opened after the basidiomata primordia formation and kept at room temperature, at $80 \%$ relative humidity.

\section{Moisture determination (\%)}

The moisture (\%) of the initial substrates and composts after the cultivation was determined in a incubator at $105^{\circ} \mathrm{C}$ in triplicate The basidiomata moisture (\%) was determined at $60^{\circ} \mathrm{C}$, in a incubator with forced air circulation.

\section{Calculation of compost consumption (CC), productivity (P) and biological efficiency (BE) percentages}

$\mathrm{CC}=100-\{$ (Final compost dry weight / Initial compost dry weight) $\mathrm{x} 100\}$

$\mathrm{P}=($ Mushroom dry weight $/$ Compost initial dry weight $) \times 100$ $\mathrm{BE}=($ Mushroom fresh weight $/$ Compost initial dry weight $) \times 100$

\section{Chemical biomass composition}

$\mathrm{Ca}, \mathrm{Mg}, \mathrm{Cu}, \mathrm{Fe}, \mathrm{Mn}$ and $\mathrm{Zn}$ were determined by atomic absorption spectrophotometry. $\mathrm{N}$ total was determined by the Kjedahl method, $\mathrm{P}$ and B by colorimetry, K by flame photometry and $\mathrm{S}$ by turbidimetry. The nitric perchloric digestion was used, with exception to N, sulphur-perchloric digestion and for B, dry digestion. The ash content was obtained in the muffle furnace after 3 hours at $550^{\circ} \mathrm{C}$. The crude protein was obtained using the conversion factor $(\mathrm{N} \times 6.25)$ and the Soxhlet device to extract the crude lipids.

\section{Statistical analysis}

The SAS program with the Npar1way procedure was used to compare the biomass production in the two composts.

\section{RESULTS AND DISCUSSION}

The daily air relative humidity (\%) and the local room temperature $\left({ }^{\circ} \mathrm{C}\right)$ averages, where the bags with the composts remained after being opened, were, respectively, $78.5 \% \pm 4.94$ and $26.8^{\circ} \mathrm{C} \pm 1.87$. The readings were taken with thermohygrometer in two periods: the first between 9:00 and $12: 00 \mathrm{~h}\left(79.3 \% \pm 3.64\right.$ and $\left.26.2^{\circ} \mathrm{C} \pm 1.72\right)$ and the second between 13:00 and $16: 00 \mathrm{~h}\left(77.7 \% \pm 5.96\right.$ and $\left.27.4^{\circ} \mathrm{C} \pm 1.87\right)$.

O. canarii (Fig. 1) showed white mycelium that colonized the entire composts surface after 21 days of incubation at $25^{\circ} \mathrm{C}$. However, in the compost with sugar-cane bagasse the colonization was faster and showed a more dense mycelium than in the compost with eucalyptus sawdust. The basidiomata primordia increased in size and elongated, becoming a rudimentary pileus. Further enlargement and differentiation produced a miniature mushroom with a stipe, pileus and hymenium covering the gills. After this point, a very rapid elongation and expansion resulted in the formation of a mature basidioma characteristic of this species. The mushrooms harvested after the pileus opening in the compost with sugarcane bagasse presented varied sizes reaching a diameter of 9 $\mathrm{cm}$ and a height of $10 \mathrm{~cm}$. The best productivity $(4.47 \% \pm 1.34)$, biological efficiency $(55.66 \% \pm 20.41)$ and compost consumption $(38.78 \% \pm 4.59)$ averages were observed in this compost.

The edible mushrooms Agrocybe perfecta and Pleurotus ostreatoroseus were cultivated in compost with sugar-cane bagasse and presented values similar to those obtained with $O$. canarii. In the compost supplemented with $20 \%$ of wheat bran, the productivity for each mushroom was $4.91 \%$ and $5.55 \%$, respectively. In addition, when the compost was supplemented with $30 \%$ of wheat bran, a higher productivity was obtained for both, A. perfecta (7.16\%) and P. ostreatoroseus (5.64\%). The compost consumption was determined only for the $P$. ostreatoroseus, $32.75 \%$ and $39.13 \%$ when the supplementation was $20 \%$ and $30 \%$ of wheat bran, respectively (5).

The basidiomata production in the compost with eucalyptus sawdust corresponded to $1 / 3$ of the one in sugar-cane bagasse. Besides the lower basidiomata production, these were smaller, with a less vigorous appearance, reaching a maximum of $5 \mathrm{~cm}$ of diameter for $6 \mathrm{~cm}$ of height. The productivity $(1.38 \% \pm 0.48)$, biological efficiency $(19.51 \% \pm 7.57)$ and compost consumption $(26.65 \% \pm 3.25)$ percentages were also inferior when compared to the cultivation in sugar-cane bagasse. The fresh mushrooms 


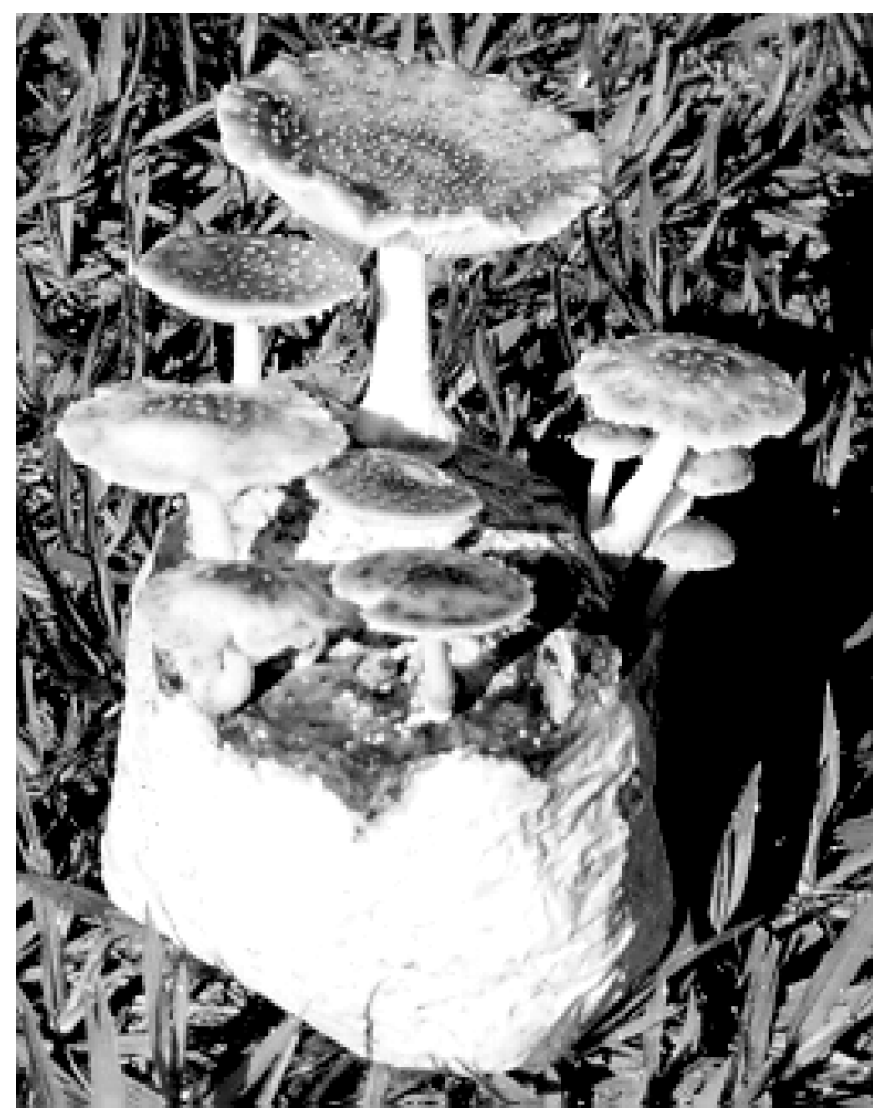

Figure 1. Oudemansiella canarii cultivated in compost with sugar-cane bagasse.

presented mild taste, soft texture, with a more consistent stipe. When stored in a refrigerator at $4^{\circ} \mathrm{C}$, they maintained good appearance and consistency for approximately 7 days.

The wet and dry biomass averages produced in the compost with sugar-cane bagasse were, respectively, $120.12 \mathrm{~g} \pm 44.13$ and $9.67 \mathrm{~g} \pm 2.89$, whereas in the compost with eucalyptus sawdust these averages were, respectively, 36.01 $\mathrm{g} \pm 13.97$ and $2.54 \mathrm{~g} \pm 0.89$. These variations were statistically significant at a $5 \%$ significance level by Wilcoxon's non-parametric statistical analysis, done with the SAS program, following the Npar1way procedure (10).

Table 1 presents the averages of four analyses of some $O$. canarii biomass constituents, taken in the dehydrated basidiomata, obtained in the composts with sugar-cane bagasse or eucalyptus sawdust. As a rule, the values found were not different among themselves, however, greater amounts were observed in the mushroom biomass cultivated in eucalyptus sawdust. In this compost, this mushroom had lower growth, therefore concentrating substances in its biomass. The high rate of $\mathrm{Cu}$ found in the mushroom biomass cultivated in eucalyptus sawdust (187.00 ppm \pm 10.13$)$, when compared with
Table 1. Analysis of some Oudemansiella canarii biomass components cultivated in sugar-cane bagasse and eucalyptus sawdust.

\begin{tabular}{lrr}
\hline $\begin{array}{l}\text { Chemical } \\
\text { Analysis }\end{array}$ & $\begin{array}{c}\text { Biomass in } \\
\text { sugar-cane } \\
\text { bagasse }\end{array}$ & $\begin{array}{c}\text { Biomass in } \\
\text { eucalyptus } \\
\text { sawdust }\end{array}$ \\
\hline Nitrogen (\%) & $3.11 \pm 0.45$ & $3.65 \pm 0.11$ \\
Phosphorous (\%) & $1.15 \pm 0.06$ & $1.35 \pm 0.13$ \\
Potassium (\%) & $3.37 \pm 0.07$ & $4.48 \pm 0.73$ \\
Calcium (\%) & $0.08 \pm 0.03$ & $0.21 \pm 0.19$ \\
Magnesium (\%) & $0.11 \pm 0.01$ & $0.13 \pm 0.01$ \\
Sulphur (\%) & $0.09 \pm 0.02$ & $0.10 \pm 0.06$ \\
Boron (ppm) & $2.30 \pm 2.57$ & $2.98 \pm 2.96$ \\
Copper (ppm) & $12.75 \pm 8.42$ & $187.00 \pm 10.13$ \\
Iron (ppm) & $75.00 \pm 16.57$ & $164.75 \pm 90.53$ \\
Manganese (ppm) & $2.25 \pm 1.50$ & $4.00 \pm 2.83$ \\
Zinc (ppm) & $46.25 \pm 8.77$ & $86.75 \pm 2.75$ \\
Proteins (\%) & $19.45 \pm 2.81$ & $22.81 \pm 0.67$ \\
Lipids (\%) & $15.85 \pm 0.41$ & $17.52 \pm 0.61$ \\
Ash (\%) & $7.26 \pm 1.05$ & $9.15 \pm 1.14$ \\
\hline
\end{tabular}

the values of the same element in the biomass cultivated in sugar-cane bagasse $(12.75 \mathrm{ppm} \pm 8.42)$, probably is due to the fact that the wood was treated with copper-based chemicals (fungicides).

These values bring out the importance of the choice of the substrate, not only looking for a better productivity, but also the quality of the final product. The product is important, but even more important is its composition. Another fact shows that the high rates of determined microelements had a toxic effect on the fungus growth, as in the case of the compost with eucalyptus sawdust, specifically with respect to $\mathrm{Cu}$. Some of the trace elements, such as $\mathrm{Cu}$ and $\mathrm{Zn}$, become toxic at levels only a few times greater than those required for optimum growth (6).

The standard deviation of the boron, copper and manganese values in the mushroom biomass obtained when sugar-cane bagasse was used as substratum, and the calcium, sulphur, boron, iron and manganese values in the mushroom biomass obtained in eucalyptus sawdust substratum presented high variability, probably caused by the low number of repetitions (four) and by the fact that the analysis were done in different times. In addition, the high variability can be explained by other experimental problems such as the heterogenous distribution of these ions in the biomass.

$O$. canarii showed great potential for future applications. However, additional studies are necessary for a better evaluation of this edible mushroom, aiming its introduction market as food. More adequate substrate composition and cultivation conditions are needed to improve biological efficiency and productivity. There is also a need to evaluate the substrate digestibility, after cultivation, as a supplement to ruminants diet. 


\section{ACKNOWLEDGMENTS}

We are grateful to FAPESP for the support and grant to the first author.

\section{RESUMO}

\section{Cultivo do cogumelo comestível Oudemansiella canarii (Jungh.) Höhn. em substratos lignocelulósicos}

O cogumelo comestível Oudemansiella canarii (Jungh.) Höhn., é comum no território brasileiro, sendo encontrado em diferentes biomas, onde colonizam várias espécies vegetais. Neste estudo, o cultivo deste basidiomiceto foi realizado em sacos plásticos contendo bagaço de cana-de-açúcar (200 g) ou serragem de eucalipto (200 g) suplementados com farelo de trigo $(50 \mathrm{~g})$. Os substratos foram esterilizados a $121^{\circ} \mathrm{C}$ por 1 hora, inoculados com $3 \mathrm{~g}$ de grãos de trigo colonizados por micélio do fungo e permaneceram incubados a $25^{\circ} \mathrm{C}$ até a formação dos primórdios dos basidiomas. Os cogumelos, colhidos após a abertura do píleo, apresentaram tamanhos variados chegando a atingir $9 \mathrm{~cm}$ de diâmetro por $10 \mathrm{~cm}$ de altura. Os cogumelos frescos apresentaram paladar suave e consistência macia e quando mantidos a $4^{\circ} \mathrm{C}$ permaneceram com bom aspecto e boa consistência por 7 dias. A maior produção de basidiomas, no período de 60 dias, foi obtida no composto com bagaço de cana-de-açúcar, sendo observadas as maiores médias de produtividade $(4,47 \% \pm 1,34)$, eficiência biológica $(55,66 \% \pm 20,41)$ e consumo do composto $(38,78 \% \pm$ $4,59)$. A análise estatística não paramétrica de Wilcoxon, utilizada para comparar a produção de biomassa nos dois substratos, apresentou diferenças estatisticamente significativas ao nível de $5 \%$.

Palavras-chave: Oudemansiella canarii, basidiomicetos, cogumelos, biodegradação, substratos sólidos.

\section{REFERENCES}

1. Akin, D.E.; Sethuraman, A.; Morrison III, W.H.; Martin, S.A.; Eriksson, K.-E.L. Microbial delignification with white rot fungi improves forage digestibility. Appl. Environ. Microbiol., 59:42744282, 1993.

2. Alexopoulos, C.J.; Mims, C.W.; Blackwell, M. Order Agaricales: The Mushrooms. In: Alexopoulos, C.J.; Mims, C.W.; Blackwell, M. Introductory mycology. John Wiley \& Sons, New York, 1996, p.508543 .

3. Blanchette, R.A. Degradation of the lignocellulose complex in wood. Can. J. Bot., 73:s999-s1010, 1995.

4. Bononi, V.L.R.; Capelari, M.; Maziero, R.; Trufem, S.F.B. Cultivo de cogumelos comestíveis. Ícone, São Paulo, 1995, 206p.

5. Capelari, M. Atividade biodegradadora e cultivo de três espécies comestíveis de basidiomicetos: Pleurotus spp. e Agrocybe perfecta (Rick) Sing. Universidade de São Paulo, São Paulo, 1996, 154p.

6. Carlile, M.J.; Watkinson, S.C. Fungal cells and vegetative grown. In: Carlile, M.J.; Watkinson, S.C. The fungi. Academic Press, London, 1996, p.77-151.

7. Chang, S.T. Mushroom and mushroom biology. In: Chang, S.T.; Buswell, J.A.; Miles, P.G. (eds). Genetics and breeding of edible mushrooms. Gordon \& Breach, Philadelphia, 1993, p.1-3.

8. Hadar, Y.; Kerem, Z.; Gorodecki, B.; Ardon, O. Utilization of lignocellulosic waste by the edible mushroom, Pleurotus. Biodegradation, 3:189-205, 1992.

9. Moore-Landecker, E. Fundamentals of the fungi. Prentice Hall, New Jersey, 1996, 574p.

10. Sokal, R.R.; Rohlf, F.J. Assumptions of analysis of variance. In: Sokal, R.R.; Rohlf, F.J. Biometry. W.H. Freeman, New York, 1995, p.392-450.

11. Zadrazil, F.; Osterman, D.; Compare, G.D. Production of edible mushrooms. In: Doelle, H.W.; Mitchell, D.A.; Rolz, C.E. (eds). Solid substrate cultivation. Elsevier, London, 1992, p.283-319. 